\title{
A IDEOLOGIA DO SOLDADO-CIDADÃO NAS ESCOLAS BRASILEIRAS: OLAVO BILAC E A LIGA DE DEFESA NACIONAL (1916)
}

Dalvit Greiner de Paula ${ }^{1}$

\begin{abstract}
Resumo
Este artigo pretende fazer uma leitura de uma obra cívica de Olavo Bilac à luz de Nicolau Maquiavel, naquilo que Maquiavel se propõe a convencer o Príncipe da necessidade do amor e da fidelidade de seus súditos para a defesa da liberdade e do território. Propomos essa leitura na área da História da Educação Cultura e Práticas Escolares, na medida em que um dos papeis centrais da educação é a coesão social e a maioria dos discursos no início do século XX preocupava-se com um esgarçamento do tecido social e moral da sociedade brasileira. Para isso faremos uma leitura comparativa das intenções pedagógicas do poeta Olavo Bilac, o Príncipe dos Poetas e inspetor de educação pública no Distrito Federal, que em sua campanha cívica deixa explicita a necessidade do soldado-cidadão tido como o primeiro e principal defensor da República. Porém, ao contrário de Maquiavel que vê na figura do soldado-cidadão um defensor da liberdade numa República, Bilac, através de seus discursos voltados a estudantes - adolescentes ou jovens, civis ou militares - vê na figura do soldado-cidadão a possibilidade de, além da defesa da ordem, limpar, educar e civilizar os homens da nascente República brasileira através de uma educação militar seja pela via do escotismo ou da caserna. Para atingir o nosso objetivo analisaremos alguns discursos do livro A Defesa Nacional (1917) que faz a propaganda da Liga de Defesa Nacional e traça um programa cívico-pedagógico para a construção deste homem novo para uma República nascente.
\end{abstract}

Palavras-chave: Educação. Cidadão. Soldado. Olavo Bilac. Liga de Defesa Nacional.

\section{THE CITIZEN-SOLDIER IDEOLOGY IN BRAZILIAN SCHOOLS: OLAVO BILAC AND THE} NATIONAL DEFENSE LEAGUE (1916)

\begin{abstract}
This article discusses one of Olavo Bilac's civic woks in the perspective of Niccolo Machiavelli who convinces the Prince that his vassals' love and loyalty are needed to defend freedom and territory. According to what proposes the History of Education, Culture and School Practice, one of the central roles of education is social cohesion and due to this the majority of speeches in the early XX century were concerned with morality in Brazilian society. For this, a comparative reading of the pedagogical intentions of poet Olavo Bilac, the Prince of Poets, a public education inspector in the Federal District, whose civic campaign highlights the need for the citizen-soldier, and who is believed to be the first and main defender of the Republic, was undertaken. However, unlike Machiavelli who advocated the figure of the citizen-soldier as a defendant of Republican freedom, Bilac, in his speeches aimed at students - teenagers or young people, civilian or military - adds to the citizen-soldier's role of defending the order, purifying, educating and civilizing men of the Brazilian republic through military education. To achieve this goal, some speeches of "The National League" (1917) book which advertises the National Defense League and draws a civiceducation program for the construction of this new Republican man were analyzed.
\end{abstract}

Keywords: Education; Citizen-Soldier; Olavo Bilac; National defense league.

\section{Introdução}

O que buscamos investigar neste artigo são os discursos proferidos por Olavo Bilac, também Patrono do Serviço Militar brasileiro, durante sua campanha cívica, naquilo que tem de convencimento à sua plateia da necessidade de amor à pátria e à República. Bilac é um defensor do

\footnotetext{
${ }^{1}$ Mestre em Educação pela UEMG - Universidade do Estado de Minas Gerais. Especialista em Gestão Cultural pela PUC-MG. Especialista em Docência do Ensino Superior pela ESAB-ES. Professor de História da Rede Municipal de Educação de Belo Horizonte/MG. E-mail: dalvit.greiner@gmail.com
} 
sorteio militar por acreditar que este é um mecanismo de fortalecimento da Democracia e da República uma vez que todo cidadão habilitado tem o dever moral de defender a sua pátria. Para isso, lançaremos mão da leitura do Príncipe, de Nicolau Maquiavel, clássico modelo de manutenção do poder do príncipe em seu principado. Analisaremos a condição do cidadão e do soldado em ambos na tentativa de entender como o discurso de Bilac impõe à Escola, em particular e à Educação, de forma geral, a responsabilidade de formar esse cidadão.

O artigo é dividido em três partes: na primeira parte buscamos entender como a defesa do território é parte da necessidade humana para prover alimentos para si e para o grupo tornando-se assim mote central dos discursos dos governantes em qualquer tempo e lugar. Assim buscamos entender esses discursos desde a Roma antiga na figura clássica do cidadão-soldado até a sua substituição por outro conceito de soldado e de cidadania nos finais da Idade Média e início da Idade Moderna europeia. Na segunda parte, buscamos este entendimento em relação ao Brasil, que substitui uma relação, aos moldes feudais, de fidelidade ao rei até meados do século XIX, por uma relação de fidelidade ao senhor proprietário de terras da segunda metade do século em diante na figura do coronel da Guarda Nacional, o que vai enfraquecer o Exército. Na terceira parte, buscamos entender nos discursos de Olavo Bilac a estratégia de reforço ideológico centrado no fortalecimento do Exército, instituição que formará o verdadeiro cidadão, na medida em que o mesmo, porta-voz da Liga de Defesa Nacional, acredita que cada escola deve se tornar um quartel e que cada quartel deve tornar-se uma escola. Este é o momento da construção da ideologia do cidadão-soldado no Brasil, onde é reclamado da escola papel fundamental na sua disseminação: o amor incondicional à Pátria e o culto aos seus símbolos.

\section{A defesa do território como necessidade humana}

A ideia do homem defendendo seu território através de armas, ou seja, da violência, está intimamente ligado à ideia de sobrevivência de si e do grupo. Ao pensarmos nos estágios iniciais da humanidade o território é o espaço natural da colheita e, portanto, lugar das lutas para a sobrevivência. A sua delimitação e defesa se tornará mais urgente e necessária com o processo de domesticação de animais e plantas. É com a delimitação, a imposição violenta de limites, e com o início do culto aos ancestrais que o fizeram que se instala a ideia de defesa do território. O exemplo mais bem-acabado é a cidade de Roma que se apresenta com "Rômulo conduzindo o arado e lançando um sulco em volta da colina que marcará dali por diante o limite sagrado da cidade" (GRANDAZZI, 2010, p. 19), momento em que se confere sacralidade à propriedade territorial.

Em seu Leviathan, discutindo a natureza humana, Thomas Hobbes (1588-1679) alerta-nos 
sobre as causas da discórdia entre os homens, que são a competição, a desconfiança e a glória, sabendo-se que:

A primeira leva os homens a atacar os outros tendo em vista o lucro; a segunda, a segurança; e a terceira, a reputação. Os primeiros usam a violência para se tornarem senhores das pessoas, mulheres, filhos e rebanhos dos outros homens; os segundos, para defendê-los; e os terceiros por ninharias, como uma palavra, um sorriso, uma diferença de opinião, e qualquer outro sinal de desprezo, quer seja diretamente dirigido a suas pessoas, quer indiretamente a seus parentes, seus amigos, sua nação, sua profissão ou seu nome (HOBBES, 1997, p. 109).

Com isso, Hobbes remete a questão da violência para o estado de natureza ao justificar essa violência como parte do ordenamento natural do homem naquele momento em que o mesmo atinge seu estado mais baixo na escala ética de um mundo racional, o campo da necessidade. Não é objetivo nesta investigação julgar se é moralmente correto apropriar-se e defender com armas um bem que é de todos, uma vez que as noções de território e propriedade, não são o resultado do trabalho sobre a terra, mas da dominação violenta sobre ela. Porém, se partirmos do princípio hobbesiano do estado de natureza essa violência torna-se amoral na medida em que a sobrevivência está ligada ao primeiro caso - o lucro - pois que o homem acumula, mesmo roubando, para garantir o seu futuro e o do seu grupo, e no segundo caso, o revide, pelos mesmos objetivos. Assim "o homem natural é quem se apodera pela força de qualquer bem, não apenas do que excede o necessário à sobrevivência - mas de tudo: matando, em vez de dominar, o outro" (RIBEIRO, 1999, p. 84), colocando o outro sempre num estado de revide, portanto, de guerra. Infelizmente, cabe-nos apenas constatar que é de vital importância para a sobrevivência do indivíduo e de seu grupo na medida em que é da terra que ele tira o seu sustento como qualquer outro ser vivo neste planeta. Consequentemente cabe-nos concordar com a hipótese de Darwin (1809-1882) citado por Freud (1856-1939) "[...] de que a forma primordial da sociedade humana foi a de uma horda governada soberanamente por um macho forte [com] traços indestrutíveis na história hereditária humana [...].” (FREUD, 2013, p. 129), assim a violência é vista como um componente natural das relações sociais e torna-se a dever de uma sociedade que quer viver em paz prever as possibilidades de conflito e prover, antecipando, se possível, as respostas necessárias para evitar a sua autodestruição.

Porém, quando falamos da glória que traz a luta, abrimos caminho para a figura do soldado profissional e do mercenário que vê na guerra e não na paz a sua razão de ser. Estamos falando do soldado aquém do cidadão, que mesmo movido pela razão (a tão temida razão de Estado) age como no estado de natureza inicial. E é nesse caráter narcísico que a ideologia do soldado vai se apoiar. Ao desfigurar, ao longo da história, as ideias de defesa de um território necessário à sobrevivência do grupo e negligenciar os avanços da tecnologia, foi-se construindo um arcabouço teórico capaz de 
sustentar no ideário das sociedades a necessidade de exércitos profissionais mantidos com altos custos mesmo em tempos de paz.

Por outro lado, o sonho de se ver livre da violência cotidiana, das ameaças e das guerras também perseguem os homens, porém a permanência daquelas atitudes belicosas contraria as previsões mais otimistas. O francês Benjamin Constant (1767-1830), em discurso no início do Século XIX, acredita que "a guerra é o impulso, o comércio é o cálculo. Mas, por isso mesmo, deve haver um momento em que o comércio substitui a guerra. Nós chegamos a esse momento." (CONSTANT, 1985, p. 2). Karl Marx (1818-1883) e Friedrich Engels (1820-1895) defendiam a ideia de que o capitalismo - sequência natural do enfraquecimento do modelo feudal - com o avanço da ciência e da tecnologia tornou-se capaz de suprir as necessidades humanas mais básicas. Portanto, podiam e afirmaram que “a 'libertação' é um fato histórico e não um fato intelectual, e é provocado por condições históricas, pelo progresso da indústria, do comércio e da agricultura." (MARX; ENGELS, 1999, p. 24).

Com a supremacia do comércio e da técnica, em princípio, não existem mais razões para que o mundo continue guerreando jogando por terra as justificativas e as ideologias que reafirmam a necessidade do homem armado. Porém, Marx e Engels nos alertam para o fato de que as mudanças nas forças produtivas engendram as mudanças nas ideologias.

Em Roma, a ideia do agricultor defendendo sua terra é condição para a cidadania. O cidadão romano e o soldado se confundem, mesmo que alguns soldados sejam parte da propriedade e marche a pé ao lado de seus senhores a cavalo. Claro que não estamos falando daquele soldado que vive de soldo e que em Roma não é o cidadão. Falamos daquele agricultor proprietário que nem sempre é maioria. Ele é um homem de bens, capaz de aglutinar outros homens e pagá-los para ajudá-lo em sua defesa e na de sua família. Assim "ao longo da vida política dos romanos, esse retrato do cidadão, que deixa o arado para assumir a suprema magistratura, encarnou o ideal do bom cidadão, do proprietário de terra, pronto a assumir a defesa de Roma.” (CORASSIN, 2006, p. 5) e, portanto, todos os cidadãos, independente de seu lugar numa sociedade censitária como era Roma, era um homem mobilizável na defesa da cidade. Sendo assim, tornam a defender não uma cidade e uma cidadania hipotéticas, mas um território demarcado pelo seu fundador, expandido pelas novas gerações, bem como as liberdades necessárias e as instituições para continuar a fazê-lo. E isso só era possível porque Roma concedia certos graus da sua cidadania aos conquistados garantindo a pax romana, um artifício ideológico que igualava os proprietários de bens e terra, acolhendo-os como, por exemplo, aos "gauleses em suas fileiras" (GRANDAZZI, 2010, p. 160), organizados em cúrias e centúrias. Para além da propriedade, da liberdade e das armas, a cidadania se manifestava através 
das assembleias.

Assim o rei, ajudado pelo Senado (senatus) - cuja etimologia indica ter sido na origem um conselho de anciãos (senes) -, convoca o povo de cidadãos-soldados, reunidos em cúria, ao qual é proposta uma decisão que ele só tem de aprovar, trazendo-lhe um sufrágio (suffragium) que nada mais é do que o barulho (fragor) das armas se entrechocando em sinal de assentimento (GRANDAZZI, 2010, p. 158).

Tais características se perdem juntamente com o império e as novas configurações da Idade Média europeia, centralizando decisões na mão de um clero e uma nobreza fundiárias, que espoliava camponeses e se exercitavam em jogos militares, num sistema recíproco de vassalagem e fidelidade a um poder central. Surge, nesse momento, homens com liberdade aventureira suficiente para não se fixarem na terra de outros, porém com a habilidade necessária aos bandidos que oferecem segurança, para se tornar um soldado mercenário a serviço de um duque, um príncipe ou um rei que disputa um pedaço de terra. Maquiavel, na Itália, os nomeia e os descreve: são os condottieri, capitães de tropas mercenárias que se fazem profissionais da conquista e da pilhagem cujo "código militar [...] tinha por objetivo evitar trabalhos e perigos [...]." (MAQUIAVEL, 1996, p. $81)$.

Com a terra pertencendo à nobreza, desaparece a figura do cidadão-soldado, naqueles moldes romanos, fazendo surgir o mercenário que tem como primeira função manter a si e ao seu grupo colocando-se a serviço de outrem. Já não está mais ligado diretamente à propriedade como sua propriedade privada, mas ligado ao rei ou nobre pelo sistema de vassalagem. Este homem que presta homenagem e jura fidelidade para honrar e defender o rei se torna o novo modelo de soldado. Em geral é um nobre de habilidades guerreiras assumindo o oficialato que é reservado à nobreza como forma de reconhecimento do rei perante os demais. Surge o exército real, desligado da propriedade, mantido a soldo do rei e da nobreza com renda proveniente da terra cultivada pelos camponeses.

Difere, portanto da ideia de um exército nacional, com outros interesses que não o do rei, muito distante do Exército de Novo Tipo de Oliver Cromwell na Inglaterra do Século XVII, já na Idade Moderna.

Ao observarmos a Inglaterra da revolução de 1640, percebemos estes dois tipos de exército se batendo: de um lado, o exército real mantido a soldo pela nobreza a partir do tesouro real, constituído com os impostos e rendas arrecadados pela coroa; do outro lado, o Exército de Novo Tipo organizado pelo Parlamento e comandado por Cromwell constituindo-se de "todos os que pegaram em armas nesta causa de Deus e seu povo, especialmente os soldados comuns" (O CATECISMO DO SOLDADO, 1644). Esse exército congregava todos os que não se alinhavam ao 
rei desde a pequena nobreza descontente até os pobres e insatisfeitos da cidade e do campo, como os quakers, diggers e levellers que imaginavam uma nova relação entre o rei e uma sociedade que se queria proprietária. Assim, o cidadão em armas da Revolução Inglesa é o defensor da propriedade, enquanto que o da Revolução Francesa é o resultado "da virtual abolição, em casa e no exterior, da distinção entre soldados e civis" (HOBSBAWN, p. 85), defensores da liberdade e de uma nação. Porém, não há contradição. Um e outro são condições para a cidadania burguesa.

É nesse clima que Thomas Hobbes defende os "homens de coragem feminina". Nessa defesa pretende esclarecer a todos do contrário que se pregava até o momento, a obrigatoriedade de se pegar em armas. Se, instado pelo medo a razão manda que os homens se organizem e entregue a sua liberdade e as armas ao Estado então tenho o direito de não lutar a guerra. Ou seja,

[Não] estou obrigado a guerrear pelo Estado. Não pode ele valer-se de minha simples obrigação contratual para chamar-me a reprimir os dissidentes internos, ou a combater os inimigos externos. Do duplo gládio, da justiça e da guerra, deve incumbir-se o próprio soberano com seus funcionários. [...] Só estou obrigado a matar meu concidadão ou o inimigo se contratei, especificamente, ser carrasco ou soldado [...] que não pertence à essência da cidadania, do serviço, da filiação: da sociabilidade" (RIBEIRO, 1999, p. 9596).

O que Ribeiro (1999) nos esclarece é que a entrega das minhas armas e da minha liberdade no contrato com o soberano tornam-me um cidadão - e aqui valem nossas atuais Constituições - mas não me tornam um soldado. $\mathrm{O}$ acordo ou contrato feito por um soldado é outro. Ele passa a ser um funcionário do Estado e, portanto, um representante a soldo desse Estado. "O soldado será então um assalariado, em vez do cidadão em armas" (idem), exceção feita à defesa do Estado e seu território quando agredido, mas nunca quando agressor. Não havendo agressões ao Estado não posso ser chamado a prestar serviços de natureza militar voluntariamente na medida em que não sou obrigado a agredir o outro que tem tanto direito à vida e à liberdade quanto eu.

Porém, a proposta para aquisição e manutenção de um principado desenvolvida por Nicolau Maquiavel (1469-1527) exige um cidadão que se quer livre e luta pela sua liberdade. Para que tal aconteça - ou permaneça - este cidadão vai se apoiar num príncipe, no caso dos principados, ou num cidadão eleito para o comando da cidade, no caso das repúblicas. Mas, para quaisquer dos casos, esta cidade buscará para si as bases ideais para sua existência "[...] e as principais bases que os Estados têm, sejam novos, velhos ou mistos, são boas leis e boas armas. E como não podem existir boas leis onde não há boas armas, e onde há boas armas convém que existam boas leis." (MAQUIAVEL, 1996, p. 77).

Para a construção deste Estado ideal, Maquiavel reconstrói a figura do cidadão romano. Ora olhando para si, um cidadão sem fortuna, mas que com sua virtù se mantém amorosamente fiel à 
sua cidade, ainda sonhando com uma Itália unificada sob um príncipe ou uma república, forte o suficiente para se manter unida, como os romanos o foram, seja na República ou no Império; ora olhando para o passado de Florença tantas vezes perdida para outras cidades por negligência ou incapacidade de seus príncipes em governá-la.

Em Maquiavel encontramos duas categorias de soldado: o soldado mercenário e aquele soldado fiel ao príncipe e à república. O mercenário é aquele que vive a soldo do príncipe e disponibiliza seu único bem: é mão de obra cuja única propriedade é o próprio corpo que se põe para a guerra na defesa de outrem. O fiel ao príncipe ou à república é aquele que ama a sua pátria e se põe em defesa de sua liberdade, de suas instituições e de sua terra.

Mas, com tropas mercenárias ou auxiliares Maquiavel não vê nenhuma possibilidade de conquista ou de manutenção de um estado porque por mais bravos e valentes que se apresentam na paz são, na verdade, tropas “[...] inúteis e perigosas [...] ambiciosas, indisciplinadas, infiéis, insolentes para com os amigos, mas covardes perante os inimigos, não temem a Deus, nem dão fé aos homens $[\ldots]$ ".. incapazes de se sacrificar pelo príncipe ou pela república.

Maquiavel demonstra com suas atitudes a principal virtude do cidadão e do soldado: o desejo de liberdade e amor à cidade seja esta um principado ou uma república. A cidade de Maquiavel é uma cidade do Século XVI. Ela já é o resultado das mudanças ocorridas no final da Idade Média. Florença é uma cidade da Renascença e o homem que a habita se quer moderno. Acredita em Deus, mas se põe no centro do mundo. É um protoburguês. É proprietário de terras, possui bens e patrimônio considerável além de empregados que lhe cuidam dos negócios. O cidadão de Maquiavel é alguém que quer "exercer livremente as suas atividades, no comércio, na agricultura e em qualquer outro terreno" (MAQUIAVEL, p. 124). Estes são chamados de grandes e verdadeiros cidadãos, pois que contribuem com dinheiro, víveres e armas para a defesa da cidade. São amigos do príncipe, ou numa república, se fazem príncipes, mesmo que por astúcia. Para além dos grandes, a cidade é composta dos pequenos agricultores, açougueiros, ferreiros, padeiros, moleiros, estalajadeiros, etc. São pessoas que não participam das decisões políticas e necessitam da proteção dos grandes.

Apesar disso, conhece muito bem a fonte de poder em cada um. Num principado, o príncipe se mantém no poder aliando-se e controlando uma elite que por fraqueza ou incapacidade não se rebela. Mantém o povo em paz e ordeiro. Numa república, o povo vendo-se em dificuldades para resistir aos fortes, eleva um seu cidadão à condição de príncipe e apoiando-lhe confere-lhe autoridade sobre todos. Dessa forma, conclui-se: “[...] os Estados bem organizados e os príncipes prudentes preocuparam-se sempre em não reduzir os grandes ao desespero e satisfazer e contentar o 
povo, porque essa é uma das questões mais importante que um príncipe deve ter em mente." (MAQUIAVEL, p. 107).

Temos, portanto, no mínimo duas categorias de cidadão. Os "grandes" e o "povo". Aos "grandes" é preciso satisfazer com alianças, benefícios e promessas de modo que se mantenham fiéis à cidade e ao seu príncipe, mas que se lhes cobrem um preço pela proteção. Eles têm condições de contribuir com braços e armas, dinheiro e víveres para a composição da defesa da cidade. A estes é dada a cavalaria, pela qualidade das despesas que esta exige em animais e armas. São cidadãos constantemente armados de quem se mantém a fidelidade pelo agrado, pelo favor, pela vaidade, pela liberdade de desenvolver seus talentos. Logo abaixo temos o "povo" que não deve estar constantemente armado, mas educado, treinado e convocado para a guerra quando necessário. Povo que deve estar sempre contente com seu príncipe e a sua posição.

Das duas categorias de cidadãos depreendem-se as duas categorias de soldados. Aos primeiros, os "grandes" são dados o direito de fala nos negócios da cidade e também da guerra. Sua instrução é constante e ao lado do príncipe. Aos demais, o "povo" apenas a obediência. São a infantaria, os infantes: sem fala e a sua instrução limita-se ao manejo do necessário em tempo de guerra, pois um povo armado é um povo perigoso até mesmo para o seu Príncipe.

Assim, Maquiavel sugere um programa educativo que envolve o aprendizado da liderança para "manter os soldados disciplinados e constantemente em exercício" (MAQUIAVEL, p. 88), as teorias sobre as guerras devendo o príncipe "ler histórias de países e considerar as ações dos grandes homens, observar como se conduziram nas guerras, examinar as razões de suas vitórias e derrotas" e a prática da arte da guerra habituando "o corpo aos incômodos naturais da vida em campanha e aprender a natureza dos lugares". Os tempos de paz devem ser aproveitados da melhor maneira possível e um simples passeio ou a visita a um amigo torna-se uma aula, motivo de aprendizagem para a guerra. Por isso, o Príncipe, aprende em outra obra - A Arte da Guerra - um diálogo de Fabrício com jovens florentinos que "a natureza não faz muitos homens bravos; a aplicação e o exercício, sim.” (MAQUIAVEL, 2002, p. 127). Em suma, duas habilidades desenvolvidas por meio da aprendizagem.

Ao concluirmos esta primeira parte percebemos que a educação do Príncipe em Maquiavel se assemelha à educação do cidadão, na medida em que o primeiro deve reproduzir no segundo as suas virtudes. Porém, o principal argumento de Maquiavel para manter os cidadãos fiéis ao seu Príncipe é acudi-los em seus desejos de liberdade e segurança para que exerçam seus talentos com tranquilidade. Liberdade essa que se manifesta na propriedade fundiária dos amigos do Príncipe em quem confiam a paz e a justiça tanto em relação aos seus iguais quanto em relação aos inferiores a 
quem é garantida a segurança. Uma educação militar e militarizada mantém a obediência que deve ser o resultado do amor ao Príncipe ou à República, motivos suficientes para o cidadão armar-se contra o outro Estado. Se se arma contra o Príncipe é porque algo falhou no processo educativo e de convencimento. O personagem Fabrício, de A Arte da Guerra, faz uma síntese do que é viver uma vida militar. Não é uma vida gananciosa: deve-se abrir mão, em nome da República e do amor ao Príncipe de todos e quaisquer ganhos da atividade militar. Esta é uma atividade voluntária, assim como deve ser toda atividade que tem por fim a manutenção do Estado. E o melhor exemplo ainda é Roma onde

Os generais voltavam contentes com seus triunfos à vida civil; e os comandados depunham as armas com maior satisfação do que as empunhavam. Todos retomavam suas atividades normais, e nunca houve ninguém que esperasse se sustentar como militar graças às suas presas (MAQUIAVEL, p. 109).

\section{Patriarca, Barão e Coronel da Guarda Nacional}

No Brasil, a ideia do cidadão defendendo a pátria toma dois caminhos distintos: o primeiro caminho é o da fidelidade ao rei. Para a oficialidade do Exército toma-se por critério o mecanismo feudal de entrega de patentes e cargos a uma nobreza militar, que vai se dedicar a jogos de guerra usando o mesmo como um trampolim de proximidade ao Imperador da jovem nação. Ainda é uma continuidade do modelo português, trazido por D. João aqui aportado em 1808. Assim se cria, em 1810, a Academia Real Militar com as funções de ensino para profissionalização da tropa.

Durante o Império, vimos um Exército se consolidando a partir da fidelidade ao Imperador. Na fundação, o Defensor Perpétuo, um pai protetor da Nação, que ama a todos indistintamente na figura dos Imperadores Pedro I e Pedro II, exercendo para isso o Poder Moderador, acima de todas as paixões pessoais e partidárias. É o grande eleitor do Império. Porém, o primeiro é mantido pelo braço forte do general Francisco de Lima e Silva, que apesar da recusa do baronato, era descendente de nobres portugueses. Com o segundo, o braço forte se transfere do Pai Francisco ao filho Luiz Alves de Lima e Silva que se tornará o único duque brasileiro - fora da realeza - e atual patrono do Exército. A hereditariedade é também uma questão de fidelidade e por isso, uma hipótese que devemos considerar é a da queda do Segundo Império à carência de uma mão forte e de confiança para a construção do Terceiro Império.

O Brasil imperial não tem um Exército moderno, pois a linha adotada tem características feudais. O soldado não é um proprietário de terras. A principal característica é a fidelidade ao Príncipe, mesmo que a soldo, pois o que deve ser defendido é o próprio rei. O país se confunde com o rei, pois que a terra é propriedade do rei e 
[...] o rei é o ápice da sociedade e teoricamente tudo depende dele, pois é ele quem distribui os bens, o mais importante dos quais é a terra, que produz renda. As pessoas possuem a terra como se ela lhes houvesse sido dada pelo rei e pudesse ser tomada por ele (CÂNDIDO, p. 90)

A outra linha adotada é a defesa da propriedade privada e para isso contribuem a criação da Guarda Nacional em 1831 e a Lei de Terras em 1850. Inicialmente a Guarda Nacional é uma força paramilitar para contenção interna da população extinguindo assim as guardas municipais subordinadas às Câmaras. A Lei de Terras visa privatizar a terra tirando-a do rei, uma resposta às tentativas de descapitalização dos fazendeiros com a iminência da libertação dos escravos. Seguindo o mesmo rumo, a ruptura com o poder central se dá na medida em que a reforma da Guarda Nacional em 1850, que será mantida com os bens e para benefícios do poder local, entrega o seu comando aos presidentes de províncias e os comandos locais são fortalecidos na figura do coronel, invariavelmente o barão local ou regional. Para a Guarda Nacional não havia necessidade de defesa do Império ou da República, mas da propriedade privada do coronel.

Nos dois casos não cabe a figura do cidadão-soldado, pois não há cidadania no sentido em que o discutimos aqui. $\mathrm{O}$ oficialato é feito de interesses ligados à propriedade ou à fidelidade ao rei. $\mathrm{A}$ incorporação dos soldados ao Exército se dá pela força, como punição por crimes ou até mesmo como punição pela condição de não-produtores - quando assentavam praça nos Permanentes -, portanto, um peso morto para a sociedade.

Este era um modelo de fidelidade que estava ligado a terra na medida em que todos os membros da Guarda Nacional deviam ter as condições necessárias de se fardarem, a si e aos que estivessem aos seus serviços e

Os Juizes de Paz farão reconhecer pelas Companhias, os seus Commandantes, e estes os Officiaes. Cada um dos Officiaes ao momento de ser reconhecido prestará juramento de fidelidade ao Imperador, e obediencia a Constituição e Leis do Imperio (BRASIL, 1831, p. 49).

Assim, como se vê, durante o Império tentou-se construir no Brasil a noção do cidadãosoldado de Maquiavel, ou seja, aquele cidadão livre que ama a liberdade personificada no seu Príncipe, que por seu turno também o defende e a quem presta juramento de fidelidade. Mas, o soldado brasileiro está descolado do seu príncipe na medida em que o seu intermediário, o oficial general é alguém ligado à propriedade que, ao final do Império, está se desligando do Imperador. Com a Lei de Terras e a reforma da Guarda Nacional, o grande proprietário, já fortalecido economicamente, cria as condições propícias para o seu fortalecimento político e militar. Seus interesses são outros. Com a iminência da abolição da escravatura e a queda do Império é preciso repensar a ideologia e construir uma nova versão para a figura do soldado. O cidadão de primeira 
classe que durante o Império vai ocupar as altas patentes da Guarda Nacional guardando a fidelidade de suas hierarquias subalternas através do apadrinhamento precisa, neste momento, de quebrar a fidelidade do Exército e seus soldados tornando-os politicamente atuantes em seu nome e não mais em nome do Imperador. As revoltas da casa, expressão de Ilmar Rohllof de Matos, não fortaleceram o Imperador e seu Exército. Apenas colocaram os liberais na condição de espera do momento propício para, ao fazer valer suas ideias, ocupassem o lugar que lhes estava reservado desde a Independência. Há uma clara transferência de fidelidade e exige-se do Exército uma nova postura diante da sociedade: a de defesa da boa sociedade e não do patrimônio imperial. Assim

[...] A primeira ideologia intervencionista girava em torno da concepção do soldado-cidadão, desenvolvida durante a Questão Militar. [...] A ideia casava-se muito bem com o positivismo civilista dos jovens oficiais e alunos de Benjamin Constant. Eles a adotaram e a usaram para justificar sua ação a 15 de novembro (CARVALHO, 1997, p. 210).

Bilac não leu o Príncipe, na medida em que as primeiras traduções para a língua portuguesa se deram em 1935, tanto em Portugal quanto no Brasil, provavelmente vertidas diretamente do italiano, mas com tradutores diferentes. De qualquer modo, tanto lá quanto cá teve a sua serventia ideológica.

Lá, oferece-se uma leitura fascista do Príncipe, com artigo introdutório de Benito Mussolini (1883-1945) servindo para justificar uma ditadura fascista que se instalava

$[\ldots]$ e de resto, $[\ldots]$ nada na brochura indica ser esta a primeira edição portuguesa d'O Príncipe e não é audácia excessiva arriscar-se que, para Francisco Morais, terá pesado mais a significação política do livro do que a sua significação cultural (CÂMARA, 2005, p. 194).

Cá, apesar de nascer no governo provisório que antecede ao Estado Novo, em tradução de Lívio Xavier (1900-1988), apresenta-se mais pelo significado cultural do que com alguma significação política nacionalista ou autoritária, na medida em que a biografia do tradutor não nos autoriza a emitir tal juízo.

Há, no entanto um imperativo em Bilac: tornar-se cidadão é tornar-se soldado na defesa da pátria. Temos aqui duas questões: é preciso, juntamente com isso criar um novo Exército composto de todos os cidadãos e é preciso, com esse cidadão criar uma pátria, um objeto de desejo que seja defendido. Para formar o Exército basta o sorteio militar que, indistintamente, faz com que todos os homens sejam soldados em potencial. Isso, por si só já é motivo de orgulho. Maior motivo de orgulho é ser sorteado para servir à Pátria criando no soldado um sentimento de defesa de todos, até mesmo daqueles que não foram sorteados com tal honraria.

De outro lado, a cidadania não se resolve por sorteio, na medida em que falamos de direitos 
que precisam ser negociados cotidianamente. Mas, quem é este homem brasileiro com quem se vai construir uma pátria. Nos “[...] sertões, os homens não são brazileiros, nem ao menos são verdadeiros homens: são viventes sem alma criadora e livre, como as feras, como os insectos, como as arvores. A maior extensão do território está povoada de analfabetos [...]” (BILAC, 1917, p. 6).

Há nos textos de Bilac uma relação das misérias morais do povo brasileiro construindo assim uma visão negativa dos brasileiros e por outro lado negando as misérias materiais impostas pela elite que o tornaram assim. Paradoxalmente, aparece uma defesa positiva do povo, naquele homem cuja educação é condição para que se faça o cidadão. Esse homem novo de Bilac é totalmente carente de instrução e a pátria, para que construa a sua própria defesa, deve educar esse homem tornando-o um cidadão perfeito. A questão é qual o modelo de cidadão se quer construir?

Da mesma forma que em Maquiavel, o súdito não deve discutir sua relação com o Príncipe, pois que este o completa e o defende, assim é a Pátria de Bilac. Ela dá o abrigo necessário a este cidadão. A positividade reside na instrução deste homem novo, mas limitada ao exercício de uma cidadania restrita ao trabalho e ao amor à Pátria. Portanto, se ao súdito do Príncipe deve-se garantir a paz para que trabalhe e produza nos terrenos de seu senhor o cidadão de Bilac requer o mínimo: apenas a instrução primária, cuidados de higiene e trabalho. Em troca, a defesa da Pátria.

\title{
O verdadeiro cidadão: 0 cidadão-soldado
}

Há uma categorização desse cidadão proposto por Bilac quando o mesmo se pergunta e responde para sua plateia:

\begin{abstract}
Mas, o que é "cidadão"?
Ha na multidão das criaturas humanas, que povoam um paiz, quatro categorias, progressivamente restrictivas: 1 , todos os habitantes ou residentes, englobadamente comprehendidos; 2 , entre os habitantes, os homens adultos, que já têm a idade e a capacidade jurídica, tendo o direito de voto; 3 , entre os homens adultos, aquelles a quem chamaremos verdadeiramente "homens", isto é, aquelles que já chegaram a um certo gráu de desenvolvimento intellectual, com a consciencia da sua razão, dos seus direitos e dos seus deveres; e emfim, 4, entre os verdadeiros "homens", os "cidadãos", aquelles que, investidos de completa cultura intellectual e moral, tendo elevação de espírito, sendo capazes de sobrepor-se aos interesses próprios, aos interesses partidarios de classe ou de campanario, podem destinar-se á sagrada missão de governar e dirigir a multidão (BILAC, 1917, p. 135-6).
\end{abstract}

Portanto, como se vê na exposição de Olavo Bilac, encontramos no Brasil quatro categorias de cidadão e de cidadania que se faz pelo aumento gradativo de direitos, sendo que os últimos teriam o direito de governar todos os demais. Essa cidadania, construída na ausência, é apenas uma reprodução da pirâmide social brasileira durante a Primeira República. Chamaremos de níveis da cidadania e em ordem decrescente. 
Na base da pirâmide temos o nível 4, a maioria dos brasileiros: pretos livres, ex-escravos, brancos pobres, mulheres, jovens e crianças, imigrantes pobres e trabalhadores braçais, todos analfabetos, sem acesso à escola. Nessa categoria, segundo a Constituição de 1891 estão os não eleitores da República brasileira.

Entre 25 e 30 milhões de habitantes em 1920 dos quais $70 \%$ eram consideradas nas linhas finais dos quadros de estatísticas como "população sem profissão ou de profissão não declarada" (BRASIL, 1930, p. 6) era esse o alvo preferencial da Liga de Defesa Nacional para a instrução primária. Este público feito de crianças, mulheres e homens "ociosos descalços, maltrapilhos, inimigos da carta do 'abc' e do banho, - animaes brutos, que de homens tem apenas a apparencia e a maldade" (BRASIL, 1930 p. 7), são apresentados como "rebotalhos da sociedade", na condição de que "esses infelizes sem consciencia, sem dignidade, sem pátria, que constituem a massa amorpha e triste da nossa multidão" (BRASIL, 1930 p. 7) é descrito por Bilac como aquele que necessita da "instrucção primaria, cívica e militar; com a capacidade para o trabalho, a instrucção profissional" (BRASIL, 1930, p. 135) como condição para que haja pátria.

O nível 3 da pirâmide é composto apenas de homens e fatalmente exclui o grupo inferior. São cidadãos que já possuem alguma renda, de algum trabalho e alguma instrução adquirida com a pouca escola a que teve acesso, pois já sabem ler e escrever e, portanto, estão aptos ao voto, uma vez que a Constituição autoriza o voto apenas aos alfabetizados. São, portanto, homens que sabem ler e escrever, capazes de provar a sua condição de pais de família, trabalhadores semiespecializados que passaram por um liceu de artes e ofícios. Aqui se encontram provavelmente os trabalhadores do comércio, pequenos artesãos, praças das forças armadas e públicas,

O nível 2 são os verdadeiros homens: aqueles que têm plena consciência de seus direitos e deveres sendo portadores de bens e luzes, mas sem o interesse direto da administração pública. São “civis e militares, políticos e homens de letras, professores e jornalistas, artistas [...] uns por maldade ou indifferença natural, outros por affectação ridícula ou tola jactância, outros por imitação" (BRASIL, 1930, p. 25) abandonaram a prática e a pregação do civismo, mas que não podem ser condenados senão pelo esquecimento do amor à pátria e aos deveres cívicos. A estes o conselho é que devem se melhorar antes de melhorar o povo, voltando os olhos à educação cívica e à inauguração de uma nova política.

O nível 1, o topo da pirâmide, estão os cidadãos: aqueles portadores de todas as luzes e com tamanho desprendimento material e moral, tão acima de todas as paixões, que são capazes de pairar acima de tudo e de todos, de forma a se capacitarem verdadeiramente para o verdadeiro governo humano, criando assim a figura do Grande Eleitor. Estes homens seriam 
[...] officiaes dignos, capazes, enthusiastas, moços, ardentes, que sejam exclusivamente officiaes, isto é: educadores e disciplinadores, adorando a sua profissão, limitando toda a sua energia e a sua fé ao exercício da sua missão, unicamente officiaes e essencialmente Brazileiros, afastados das lutas partidárias, religiosas ou política, porque qualquer partidarismo diminue o valor moral do oficial [...] (BRASIL, 1930, p. 139-140).

Acrescente-se aqui o uso da língua pátria, um distintivo do cidadão que são aqueles "homens conscientes que a leem e escrevem" (BRASIL, 1930, p. 65). Portanto, a condição de alfabetizado é fundamental para o entendimento da cidadania de Bilac, porém, não apenas a alfabetização, mas a consciência que traduzimos aqui como o letramento necessário ao uso da leitura e da escrita.

Seria este o papel reservado por Bilac ao Exército? O soldado já não é mais o praça. Sequer é o praça graduado - sargentos e subtenentes - mas o oficial de patente superior. E superior porque deve trazer em si tamanha envergadura moral e cívica que o coloca acima de tudo e de todos. Ele foi educado para isso numa instituição que tem como seu fim último a defesa integral da pátria, pois a Liga de Defesa Nacional, através de seu mais ardente propagandista afirma que quer e sempre quis

[...] a instrucção e a defesa do paiz pelos livros e pelas armas. Quero a escola dentro do quartel, e o quartel dentro da escola. A segurança das pátrias depende da intelligencia e da força: o estudo defendendo a civilização, e a disciplina defendendo o estudo (BRASIL, 1930, p. 99-100).

Este cidadão-soldado defende a pátria e os seus cidadãos não-soldados. Ele intervém na salvação da nação. Portanto, os demais cidadãos não podem ter medo do soldado porque assim teria medo de si mesmo.

Na contramão, os comunistas e anarquistas, imigrantes recém-chegados às terras brasileiras portanto, não falantes da língua portuguesa, não crentes da mesma cultura - não são cidadãos, pois que negam a ideia de pátria. Os sem-pátria não podem ser cidadãos de pátria alguma.

A ideia de defesa nacional construída por Bilac desloca a ideia de defesa pragmática do território como local de criação de culto ao passado e cultura do presente. Retomando as ideias de Thomas Hobbes sobre a violência humana, de agredir por ninharias e por bobagens, por algo maldito dirigido a sua pessoa, constrói-se a ideologia de qualquer força armada de qualquer nação baseada na atitude apaixonada, sem o uso da razão. O contrário, pois de qualquer ideia de cidadania e cidadão, ou seja, aquele que evita qualquer confronto de força resolvendo-os pela negociação racional de ambas as partes.

Assim, Bilac explica a necessidade de defesa da nação a partir de uma visão biológica da defesa individual. O animal acuado pelo outro ou pela fome. No caso de um grupo, os grandes devem defender os pequenos para que o mal não se espalhe. Nessa metáfora biológica São Paulo, 
Rio e Minas Gerais são os grandes, os demais estados, pequenos. Porém, nessa analogia com a biologia, Bilac pensa nos homens de grande porte físico, quase como o grande irmão protetor, o pai que defende a família, a mãe que defende a cria. O pastor que defende o rebanho. Nessa escala que se inicia com o indivíduo garantindo a sua defesa individual, a defesa da nação é o objetivo principal, deslocada do real, mas presa ao mesmo por uma corrente moral resultante de um processo educativo em que "a dignidade e a poesia, a nobreza moral e o brio fortalecem e espiritualizam o esforço. Já não é a conservação que se defende" (BILAC, p. 128). Dessa forma, através da espiritualização do esforço justificada no ideal da pátria e no amor ao povo ultrapassa-se a necessidade de conservação do indivíduo e do grupo, justificativa biológica e hobbesiana para a violência.

Há uma contradição: Bilac se diz pacifista, mas quer a nação em condições de guerrear. Não ofensivamente, mas defensivamente. Para isso, propõe-se a divulgar uma cultura cívica necessária à justificação da guerra, como em Maquiavel que põe no amor e na fidelidade ao Príncipe que protege o súdito a motivação para o uso de armas. Ou seja, estamos falando da honra - uma virtude masculina e guerreira. Então

A nação não se arma unicamente para proteger a sua alimentação collectiva, as suas searas, as suas sinas, os seus negócios, os seus gados, os seus celleiros; armase também, para proteger o seu território, a sua possessão material e moral, as memórias dos seus maiores, a religião dos seus lares e dos seus templos, as relíquias das suas tradições, o thesouro da sua língua e da sua poesia, o culto do seu passado, o seu nome de nação (BILAC, p. 129).

Assim, apela-se para a honra do homem, ofendendo-lhe os brios, negando-lhe, além dos direitos naturais, o direito da sua conservação, de sentir medo da guerra, de buscar a sua preservação por outros meios, de recusar-se ao alistamento como forma de conservar a sua vida. A ideia de se realizar o sorteio militar no Brasil, "lei benigna, que não desorganizará o labor e a ventura dos lares" (BILAC, p. 62), longe de ser uma forma de equiparação social para todos aqueles que estivessem em condições físicas de guerrear torna-se, mais uma vez, uma maneira de obrigar o homem livre e pobre a dispor o seu corpo em defesa de uma elite que lhe negava todos os demais direitos. Para encerrar a compulsoriedade em relação aos pobres, através da ideologia da defesa nacional como responsabilidade de todos, era preciso buscar uma forma de convencimento. $\mathrm{O}$ sorteio militar não colocou os filhos da elite das fileiras do exército ou da marinha. Bilac, em seu discurso, maldiz este homem colocando-o na condição de "[...] desgraçado o animal inferior ou superior, que não pode defender e conservar a sua nutrição! E desgraçado o paíz, que não pode defender e conservar a sua liberdade e o seu trabalho, e, com a sua liberdade e o seu trabalho, a sua honra." (BILAC, p; 129) 
Este cidadão deve ser educado para tal fim. Onde? Como se fará a educação desse cidadão de quarta classe para que ele alcance e ofereça a sua máxima potência ao serviço da nação? Assim como em Maquiavel que vê em todo e qualquer momento e lugar a oportunidade e possibilidade de educação do príncipe e seus súditos. Bilac nos assegura que é "[...] pela educação methódica e progressiva, pela gymnastica physica e moral [...]" (MAQUIAVEL, p. 130) adiantando-nos que "o programma está assentado, e é simples e velho: a educação civica, firmando-se na instrucção primaria, profissional e militar.” (MAQUIAVEL, p. 25).

Propõe então três níveis de instrução: a) a instrução primária, que tem como pressuposto a higiene e a moral cívica de forma a garantir aquele mínimo necessário ao entendimento de defesa da pátria e o mínimo de instrução para o trabalho, pois a escola, em seu papel civilizador "[...] é o asseio obrigatório, a hygiene obrigatoria, a regeneração muscular e psychica obrigatória [...]” (MAQUIAVEL, p. 7); b) a instrução profissional que garantiria um corpo técnico para o exercício daquelas profissões mais bem fundadas na leitura e na escrita "[...] destinada a fins artísticoliberaes, artístico-industriaes, agronomicos, náuticos e commerciaes [...]” (MAQUIAVEL, p. 136), conforme expõe o Censo de 1920, uma pequena parte da população; c) a instrução militar que elevaria o homem ao seu máximo tanto em termos morais quanto intelectuais e o colocaria totalmente devotado ao serviço da pátria. Assim, Bilac propõe uma hierarquia programática: a educação moral e cívica deve permear todo o programa de uma maneira geral, e havendo uma instrução primária para todos, profissional para alguns e militar para aqueles de grande nobreza e altruísmo. Por fim, àquele que recebeu a instrução militar, por um imperativo ético, um alerta: deve também "já sendo soldados, sede instructores" (MAQUIAVEL, p. 84).

Para completar a obra cívica a Liga de Defesa Nacional se propõe a organizar e animar "batalhões de linha de tiro e de escoteiros (MAQUIAVEL, p. 62) lutando constantemente por uma instrução primária e profissional. O coroamento desse processo educacional se dá quando se propõe a dar "às mãos de cada professor e de cada estudante, de cada patrão e de cada operário, de cada official e de cada soldado, um catecismo cívico. (MAQUIAVEL, p. 62). Assim, a escola se confunde com o quartel e a caserna torna-se "um filtro admirável, em que os homens se depuram e apuram" (MAQUIAVEL, p. 7), opinião levada a termo pelo tenente Juarez Távora durante o processo revolucionário de 1930, citado por Carvalho (1997) ao afirmar que "[...] a força armada é hoje parte integrante do povo, de cujo seio saem soldados e oficiais e para onde voltam aqueles depois de um curto tempo de estágio na caserna." (CARVALHO, 1997, p. 211).

Cabe à escola a difusão desses novos valores que são a higiene, o trabalho adestrado e a honra. Nela se resume todo o homem, pois que "a idéa da honra, abstracção sagrada, inclue em si 
muitas idéas: a da fidelidade, a do valor, a da equidade, a da responsabilidade, a do pundonor, a da indulgencia, a da confiança, a da firmeza de caracter. (BILAC, 1917, p. 73). Num país de pobres e analfabetos, considerados culpados e não vítimas pela sua situação por não terem buscado a instrução necessária para sair da situação de brutalidade em que se encontravam, a escola e a instrução cívica são apresentadas como redentores da população e não como um direito para se chegar à condição plena de cidadão. Trocam-se valores que se aproximam do individualismo liberal - como a liberdade de ação e associação para defesa dos interesses e que não servem para a maioria da população pois são levados a termos por anarquistas e comunistas - para propor uma "abstração sagrada" que a ideia de honra, resultado de um ideal nacionalista que vê neste novo cidadão-soldado apenas o defensor da pátria e não o seu questionador, pois que tais valores elencados pela Liga de Defesa Nacional mantém o homem honrado quieto e paciente, confiantes do investimento no seu crescimento moral na certeza de que "fructificarão na edade madura [...] honrados como dirigidos e dirigentes" (BILAC, 1917, p. 73).

O modelo de escola é a "[...] dos escoteiros, uma das cellulas primarias do organismo da educação cívica e da defesa nacional” (BILAC, 1917, p. 67), torna-se o ideal de toda escola para meninos na concepção de Bilac. Em discurso aos escoteiros de Belo Horizonte, no ano de 1916, Bilac expõe sua admiração inequívoca ao pensamento de Baden Powell (1857-1941), corroborandoo no pensamento de Platão e Spencer, compreendendo todo um programa didático-pedagógico mostrando como o viver ao ar livre é condição para a completude humana.

Mais claro é citar-lhe textualmente:

Esta admirável escola ao ar livre abrange todos os pontos, que se contêm o progranma da moderna pedagogia. Primeiro, a instrucção physica: a conservação ou o restabelecimento da saúde, pela hygiene e pela medicina, e o desenvolvimento normal e progressivo de todas funções do corpo, pela gymnastica e pelos jogos escolares.

Depois, a instrucção intellectual: o amestramento dos cinco sentidos, a percepção externa e interna, a cognição e a experiência; a consciência, a personalidade, e a liberdade; a faculdade de conservação - a memória; e as faculdades de elaboração - a attenção, a abstracção, a generalização, o juízo, o raciocínio, e a imaginação. Enfim, a instrucção moral; a sensibilidade, e a sua cultura; o amor próprio, o amor e o respeito da propriedade, do livre arbítrio, da independência, da emulação; o altruísmo, a benevolência, a beneficência, a amizade, a docilidade; o amor da pátria, do bello e do bem; o brio, a coragem, a disciplina; e a cultura da vontade, e a formação do caracter. E este curso completo de adestramento é feito no seio da natureza, na alegria da vida desportiva, pelo gosto próprio, pela pratica, pela lição das cousas (BILAC, 1917, p. 68-69).

Pela ordem, em primeiro lugar a educação do corpo, o controle sobre o corpo e a saúde antecipando a educação física escolar do período getulista do lema mens sana corpore sano do 
poeta romano Juvenal. Para isso, uma instrução física que promova através dos exercícios e jogos escolares o completo desenvolvimento do corpo preparando-o para a recepção dos saberes intelectuais. A manutenção e o preparo de um corpo sadio eram o primeiro passo na busca da perfeição física permitindo assim a introdução de novas habilidades. Seguindo o seu programa, Bilac propõe o controle dos apetites e das paixões através de um completo adestramento físico e intelectual do corpo educando os cinco sentidos. Portanto, em segundo lugar, habilidades inerentes à percepção externa, o estar no mundo e conservar-se nele; usar dos cinco sentidos como forma de apreender o mundo e dele tirar todo o proveito possível. Obtida tais habilidades, passa o menino para a terceira e última etapa de sua formação: a formação moral. Não é uma lista de habilidades a serem apreendidas, mas de valores para viver nessa nova pátria republicana e liberal que vem se constituindo. Listados, apresentam-se como valores individuais na sua posição diante da sociedade e dentre eles o respeito à propriedade e o livre arbítrio; na seqüência, aqueles valores de compreensão aos mais fracos, despossuídos dos direitos atingidos pelos educados nesse programa como o altruísmo, a benevolência e a beneficência. Uma relação de bondade para com os demais que não atingiram essa condição de cidadão completo e perfeito.

Assim, o pensamento da Liga de Defesa Nacional exposto por Olavo Bilac encontra-se com o receituário de Maquiavel que, na voz da personagem Fabrício em A Arte da Guerra, esclarece as virtudes que o Príncipe deve promover nos seus súditos para atingir a tranqüilidade e a paz no seu principado. Ouçamos Fabrício:

Honrar e premiar a coragem; não desprezar a pobreza; amar os hábitos e as instituições da disciplina militar; induzir os cidadãos a se amarem mutuamente, a viver sem avidez, a buscar menos o interesse privado e mais o interesse público; e outras coisas semelhantes que facilmente se poderiam ajustar aos tempos atuais (MAQUIAVEL, 2002, p. 106).

Ou seja, manter a quietude social pela conformação do corpo e da mente. Diminuir o interesse privado e buscar, desinteressadamente, o interesse público, eliminando as vontades e necessidades. Como? "A chave para reduzir o conflito entre o ideal e psique é a educação. Ela é uma das principais instituições, se não a principal, na socialização humana" (RIBEIRO, 2001, p. 71). Para o bem ou para o mal.

Mais tarde, interpelado pela plateia gaúcha com relação a um dito em São Paulo, Bilac retifica-se, o quartel não pode ser o único lugar da educação. Então esclarece: "Quero a escola dentro do quartel, e o quartel dentro da escola. A segurança das pátrias depende da intelligencia e da força: o estudo defendendo a civilização, e a disciplina defendendo o estudo" (BILAC, 1917, p. 99100). O serviço militar deveria entrar no currículo de vida de nossos jovens do sexo masculino, 
promovendo em todos, na visão de Bilac, não apenas o desejo, mas o direito de servir à pátria. Como afirmamos acima "O exercito nacional será um laboratório de civismo: uma escola de humanidade, dentro do patriotismo; uma escola de energia social, começando por ser uma escola de energia nacional.” (BILAC, 1917, p. 100). Há aqui uma confusão, não no sentido negativo da palavra, mas positivo: de misturar as coisas até torná-las indistintas, entre a escola e o quartel. Ambas teriam a mesma função na sociedade, donde vem muitas vezes o desejo da sociedade e de muitos professores de exigir a disciplina militar para a consecução dos estudos nas escolas. Todos os brasileiros devem passar pelo quartel como forma de se tornarem cidadãos completos. A cidadania é expressa na seguinte formulação:

E não queremos somente o quartel. Queremos que dentro de cada quartel haja uma aula primária; e que ao lado de cada quartel haja uma aula profissional. Ao cabo do seu tempo de aprendizado cívico, cada homem será um homem completo, um cidadão, com a sua intelligencia adestrada, com a sua capacidade armada para o trabalho, com a sua consciência formada, com os seus músculos fortalecidos, com a sua alma enobrecida (BILAC, 1917, p. 139).

Dessa forma, dentro do quartel todos receberiam o mínimo que é uma aula primária. Anexo ao quartel, ao lado, uma aula profissional. O que deixa claro que o mínimo já foi ofertado e providenciado dentro do quartel, estando aquele cidadão do nível 4, na base da pirâmide social, já pronto para viver em sociedade. Caso o desejasse, ao lado do quartel teríamos uma aula profissional, não para todos. E conclui com uma certeza assustadora de que o nivelamento das classes e dos interesses em disputa na sociedade estaria resolvido com o adestramento da inteligência e os músculos fortalecidos: "No quartel, cada homem, encontrará a sua completa cultura indispensável” (BILAC, 1917, p. 139). A confusão se completa quando se exige que, "no quartel, o official deve ser, como o professor na escola primaria: um sacerdote, um director de intelligencias e de caracteres (BILAC, 1917, p. 105). Deixando claro qual é o papel do professor e do oficial militar na formação do cidadão reforça-o afirmando que os educadores são "os professores normaes do grande exército sem profissão militar" (BILAC, 1917, p. 138).

\section{Conclusão}

Dentro de um contexto de extremo nacionalismo, onde a questão social não era vista como um caso de política, mas de polícia, na medida em que estrangeiros imigrantes trouxeram novas ideias e novas práticas políticas confrontando o governo e o Estado brasileiro, surge a Liga de Defesa Nacional composta pelo que de melhor tivemos, à época, da intelligentsia nacional. Dentro do programa da Liga, e fazendo parte de sua atuação, a ideologia do cidadão-soldado, cujo 
sentimento patriótico fosse capaz de compreender a situação de urgência em que se encontravam as nações do mundo inteiro, durante a Primeira Guerra Mundial. Torna-se prioridade na pregação de Olavo Bilac a proposta de uma educação que construísse esse novo homem que o momento exigia. Bilac entende a grandeza do país a partir do investimento governamental numa educação que tirasse o povo da sua brutalidade e o preparasse para a cidadania, mesmo que restritiva. Porém, constrói um arcabouço teórico que funde escolas e quartéis com objetivos comuns de higienizar e educar esse cidadão, conferindo a oficiais e professores funções sociais idênticas.

Diferente, pois do cidadão-soldado da Roma antiga que era proprietário de um pedaço de terra e que desaparece com o período feudal na Europa, ressurgindo no mundo moderno de duas formas: o cidadão-soldado de Maquiavel que honra o príncipe que o protege, a si e à sua propriedade, como uma crítica ao soldado mercenário; e o cidadão-soldado de extrato popular que surge na Inglaterra em defesa da propriedade e na França em defesa da liberdade. Desse novo cidadão-soldado a ideologia que se sobressai no Brasil é a de Maquiavel onde proprietários de terra vão compor a oficialidade do Exército e da Guarda Nacional na condição de vassalos do imperador. Porém, com o advento da República e o enfraquecimento do ideal do cidadão-soldado, constrói-se nova ideologia substituindo o amor ao príncipe pelo amor à pátria.

Naqueles quatrocentos anos de escrita e divulgação d'O Príncipe de Maquiavel e hoje, passados quinhentos anos, percebemos aproximações nas duas literaturas. Porém, é possível que algum círculo intelectual conhecesse e comemorasse os quatrocentos anos da obra de Maquiavel. Não encontramos nenhum documento que nos confirmasse a leitura de Maquiavel por Olavo Bilac, nem o sabemos se o tinha em sua biblioteca. A primeira tradução se dá em 1935 - Em Portugal e no Brasil -, mas nada impedia Bilac de ter contato com a obra em seu original. Com a unificação italiana em 1870 e o Risorgimento de sua literatura do início da Idade Moderna, Maquiavel surge como teórico da unidade nacional e do nacionalismo. Várias propostas expostas nos discursos de Bilac encontram-se bem desenvolvidas n'O Príncipe, porém são ampliadas e vulgarizadas nos discursos sobre a Defesa Nacional substituindo-se o amor ao príncipe pelo amor à pátria. A outra novidade é a atribuição dessa função à escola.

$\mathrm{Na}$ falta de um mito fundador, a ideia de pátria é desenvolvida por Bilac neste e em outros escritos seus como algo superior a tudo e a todos, que conduz e protege, colocando o povo na condição de amante ardoroso e incondicional desta abstração tão questionada por anarquistas e comunistas. A pátria é algo de sagrado que nivela as pessoas em seu sentimento de igualdade e por isso requer a sua defesa. Não lhe cabem questionamentos. Assim como o príncipe, a pátria é objeto de culto constante. A escola é o alvo preferencial de atuação de Bilac e da Liga de Defesa Nacional 
por acreditarem na educação como o motor ideológico, tecnológico e espiritual de um povo. A nação só atingiria sua grandeza na popularização da educação, levando a língua e as letras nacionais a todos em todos os cantos do país. Para Bilac é aí que reside a força da nação, na medida em que o analfabetismo é visto como a pior das doenças do corpo social, pois torna as pessoas incapazes cívica e moralmente.

Assim, Bilac aconselha que "na alma da criança devem ser regadas as boas acções, que florescerão na mocidade e fructificarão na edade madura. [...] Dando a um menino, depois da força e da inteligência, a honra - esse menino será um homem perfeito”. (BILAC, 1917, p. 73). Maquiavel também usa a metáfora da planta que deve ser cuidada desde a muda, para aconselhar o Príncipe nos investimentos necessários à manutenção de seu principado em perfeita ordem, pois “quem age assim planta árvores sob cuja sombra se vive mais feliz e satisfeito. (MAQUIAVEL, 2002, p. 106). Tanto o Príncipe quanto a Pátria querem esse cidadão perfeito que o amem incondicionalmente.

E aqui deparamos com outra questão que necessita maior investimento na pesquisa. A classificação da cidadania proposta por Bilac naqueles quatro níveis chama a atenção para a perfeição moral do cidadão que se identifica prontamente com um oficial do Exército Brasileiro, alçado à condição de um semideus, acima de todas as paixões que movem a atividade política, fazendo das forças armadas o Poder Moderador e por fim o grande eleitor do século XX. É notório o elogio de Bilac àqueles que retornaram à caserna abandonando a atividade partidária; é notório o elogio de Bilac às intervenções dos militares na história do país, até então. Não estariam aqui os germes das justificativas morais das intervenções militares no Brasil? No seu círculo de intelectuais militares encontramos Euclides de Oliveira Figueiredo (1883-1963), um jovem turco, pai do militarpresidente João Batista de Oliveira Figueiredo (1979-1985), escrevendo n’A Defesa Nacional, revista militar da época, também de propósitos nacionalista e moralizante. Os meninos e rapazes que ouviram as ideias de Bilac naqueles longínquos anos 1910 eram tenentes nos anos 1930 e generais em 1960. O sentimento de honra e amor à pátria provavelmente influenciou tais decisões. É preciso entender mais e melhor essa história.

Ideias que visam igualar crianças ainda encontram eco suficiente em nossa sociedade que acredita que é de pequeno que se torce o pepino, para usarmos outra metáfora vegetal, pois que é na infância (no infante, naquele que não fala) que se deve desenvolver valores. Guardamos muitos resquícios dessa pregação como os uniformes escolares, as filas no interior das escolas, os cantos cívicos e religiosos sem nenhum questionamento ou com um ensinamento vazio do amor à pátria $\mathrm{e}$, por fim, do desejo da parte de pais e professores da rigidez disciplinar de um quartel exposto nos 
altos índices de aproveitamento acadêmico das atuais escolas militares.

\section{Fonte}

BILAC, Olavo. A Defesa Nacional (discursos). Rio de Janeiro: Edição da Liga de Defesa Nacional, 1917. O documento é parte do acervo digital da USP integrante do projeto Brasiliana Digital, disponível em http://www.brasiliana.usp.br/bbd/handle/1918/00291000.

\section{Referências}

BRASIL. Câmara dos Deputados. Lei de 18 de agosto de 1831. Institui a Guarda Nacional, disponível em www.camara.gov.br

BRASIL. Ministério da Agricultura, Indústria e Commercio, Directoria Geral de Estatística. Recenseamento do Brazil, Volume IV - 5. parte - Tomo II, Rio de Janeiro: Typographia da Estatística, 1930.

CÂNDIDO, Antônio. A culpa dos reis: mando e transgressão no Ricardo II. In: NOVAIS, Adauto. São Paulo: Companhia das Letras; Secretaria Municipal de Cultura, 1992. p. 87-99.

CÂMARA, João Bettencourt da. A Primeira Edição Portuguesa d'O Príncipe ou o Maquiavel Fascista de Francisco Morais. RES-PUBLICA, Revista Lusófona de Ciência Política e Relações Internacionais, Lisboa, n. 1, p. 193-218, 2005.

CARVALHO, José Murilo de. As Forças Armadas na Primeira República: o poder desestabilizador. In: O Brasil Republicano, tomo III: sociedade e instituições (1889-1930). Rio de Janeiro:

Bertrand Brasil, 1997. p. 181-234.

CATECISMO DO SOLDADO, O. Panfleto. Disponível em http://easyweb.easynet.co.uk/ crossby/ECW/history/nma.html.

CONSTANT, Benjamin. Da liberdade dos antigos comparada à dos modernos. Revista Filosofia Política, Porto Alegre, n. 2, 1985.

CORASSIN, Maria Luiza. O cidadão romano na República. Projeto História. São Paulo, n. 33, p. 271-287, dez. 2006.

FREUD, Sigmund. Psicologia das massas e análise do eu. Porto Alegre, RS: L\&PM, 2013.

GRANDAZZI, Alexandre. As origens de Roma. Tradução Christiane Gradvohi Colas. São Paulo: Ed. UNESP, 2010.

HOBBES, Thomas. Leviatã ou Matéria, forma e poder de um Estado eclesiástico e civil. Tradução João Paulo Monteiro; Maria Beatriz Nizza da Silva. São Paulo: Nova Cultural, 1997.

HOBSBAWN, Eric J. A era das revoluções: Europa 1789-1848. 4. ed. Tradução Maria Tereza Lopes Teixeira; Marcos Penchel. Rio de Janeiro: Paz e Terra, 1982.

MAQUIAVEL, Nicolau. O Príncipe. Rio de Janeiro: Rocket, 1996. Disponível em www.jahr.com.br 
. A arte da guerra. Tradução Jean Melville. São Paulo: Martin Claret, 2002.

MARX; ENGELS. A Ideologia Alemã. Rio de Janeiro: Rocket, 1999. Disponível em www.jahr.com.br

PENA, Luiz Carlos Martins. O juiz de paz da roça. MinC/Fundação Nacional do Livro/Departamento Nacional do Livro. Disponível em: www.minc.gov.br

RIBEIRO, Renato Janine. Ao leitor sem medo: Hobbes escrevendo contra o seu tempo. 2. ed. Belo Horizonte: Ed. UFMG, 1999.

A República. São Paulo: Publifolha, 2001. 